\title{
Sun-Induced Changes in Stratum Corneum Function Are Gender and Dose Dependent in a Chinese Population
}

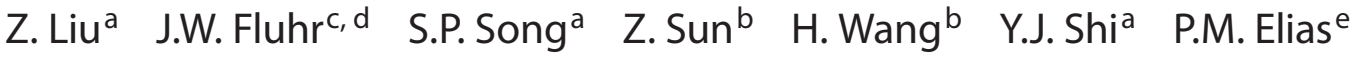 \\ M.-Q. Man ${ }^{\mathrm{e}}$

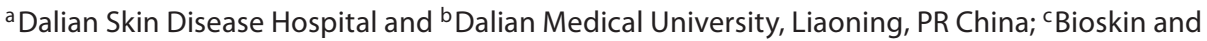 \\ ${ }^{\mathrm{d}}$ Department of Dermatology, Charité University Clinic Berlin, Berlin, Germany; ${ }^{\mathrm{e}}$ Department of Dermatology, \\ University of California School of Medicine, San Francisco, Calif., USA
}

\section{Key Words}

Stratum corneum $\cdot$ Hydration - Epidermal permeability

barrier function $\cdot$ Gender $\cdot$ Stratum corneum resistance

\begin{abstract}
Previous studies have demonstrated that UVB radiation changes the epidermal permeability barrier and stratum corneum (SC) hydration. It is well known that sun exposure causes erythema, sunburn and melanoma. However, whether daily sun exposure alters SC integrity and epidermal permeability barrier function is largely unknown, especially in Chinese subjects. In the present study, we assess the SC integrity, SC hydration and epidermal permeability barrier function following various doses of sun exposure. A total of 258 subjects ( 124 males and 134 females) aged $18-50$ years were enrolled. A multifunctional skin physiology monitor (Courage \& Khazaka MPA5) was used to measure SC hydration and transepidermal water loss (TEWL) on the forearms. In males, basal TEWL was higher with higher doses of sun exposure than with lower doses and control, whereas in females, basal TEWL was higher with lower doses of sun exposure than with higher doses and control. In the group with higher doses of sun exposure, TEWL in females was significantly lower than that in males. The barrier recovery was faster in females than in males in both control and lower-dose
\end{abstract}

groups. In both males and females, barrier recovery was delayed with higher doses of sun exposure. In males, sun exposure did not alter SC hydration, while in females SC hydration was lower with lower doses of sun exposure as compared with control and higher doses of sun exposure. These results demonstrated that sun-induced changes in SC function and SC hydration vary with gender and the extent of sun exposure.

Copyright $\odot 2010$ S. Karger AG, Basel

\section{Introduction}

The alteration in cutaneous function induced by sun exposure is mainly attributed to ultraviolet (UV) radiation. Studies have demonstrated that UVB radiation causes a variety of changes in cutaneous function. For example, there is a higher incidence of acquired melanocytic naevi in sun-exposed sites $[1,2]$. The incidence and number of melanocytic naevi are associated with the cumulative sun exposure [3-5]. Moreover, the risk of developing squamous cell carcinomas, skin malignant melanomas and actinic keratoses is strongly associated with lifetime sun exposure [6-10]. Chronic sun exposure is considered to be the major cause for non-melanoma skin cancers [11]. Most squamous cell carcinomas and basal

\section{KARGER}

() 2010 S. Karger AG, Basel

Fax +4161306 1234 E-Mail karger@karger.ch www.karger.com www.karger.com/spp
Mao-Qiang Man, MD

Dermatology Service (190)

4150 Clement Street

San Francisco, CA 94121 (USA)

Tel. +1 415750 2091, Fax +1 415750 2106, E-Mail mqman@ hotmail.com 
cell carcinomas are found on the sun-exposed body sites [12]. Furthermore, many dermatoses, such as solar urticaria, actinic dermatitis, rosacea and lupus erythematosus, are induced or exacerbated by sun exposure [13-15]. Finally, photo-aging is another common clinical problem induced by sun exposure. In addition to hyperpigmentation and sunburn, sun exposure induces formation of large wrinkles, increases skin surface roughness and reduces skin elasticity [16-19]. The number of wrinkles in humans is significantly related to total hours of sun exposure in life [20]. In animal models, UVB radiation suppresses the immune response to hepatitis $B$ vaccination, tuberculosis and leishmanial infection [21-24] and cutaneous delayed hypersensitivity $[22,25,26]$.

Likewise, with regard to stratum corneum (SC) biophysical properties, sun exposure causes dramatic changes. For instance, SC hydration is lower in sun-exposed sites in comparison with non-sun-exposed contralateral sites despite unchanged basal permeability barrier function [16]. Basal transepidermal water loss (TEWL) in human skin increases significantly following UVB radiations of 0.75 minimal erythema dose and is accompanied by decreased SC hydration and an increased melanin index [27]. Humans living in higher UV-exposed regions exhibit lower SC hydration $[19,28]$. In photo-aged skin, barrier recovery is delayed as compared with chronologically aged skin, although the basal barrier function and SC integrity show no change [29]. In animal models, UVB radiation decreases SC water content [30-32]. Moreover, UVB radiation decreases epidermal permeability barrier function and disturbs the epidermal calcium gradient [33-36]. The changes in epidermal barrier function induced by UVB radiation are associated with radiation doses. While higher doses of UVB radiation perturb barrier function, lower doses (suberythemal doses) accelerate barrier recovery [37]. However, the differences in SC biophysical properties such as barrier function and SC integrity among various doses of sun exposure have not yet been documented. In the present studies, we measure the SC integrity, SC hydration and epidermal permeability barrier function following various doses of sun exposure in males and females aged $15-50$ years in a normal Chinese population.

\section{Subjects and Methods}

\section{Subjects}

A total of 258 volunteers with skin types III or IV (Fitzpatrick classification) aged 18-50 years (124 males and 134 females; mean age $27.90 \pm 0.58$ years) were enrolled in this study. According to their daily direct sun exposure time in the last 5 days, the subjects were divided into: (a) a control group whose daily direct sun exposure time was less than $1 \mathrm{~h}$ and without direct sun exposure between 11.00 a.m. and 1.00 p.m.; (b) a group exposed to lower doses of sunlight whose daily direct sun exposure time was 1-2 $\mathrm{h}$ and without direct sun exposure between 11.00 a.m. and 1.00 p.m., and (c) a group exposed to higher doses of sunlight whose daily direct sun exposure time was $4-6 \mathrm{~h}$ and with direct sun exposure between 11.00 a.m. and 1.00 p.m. No skin care products were applied to measured sites $24 \mathrm{~h}$ prior to taking the measurement, and the measured sites were not washed with soaps or surfactants for at least $12 \mathrm{~h}$ prior to the study. There was no sign of sunburn on the measured sites.

\section{Measurements}

All measurements were randomly performed by 2 well-trained dermatologists. TEWL and SC capacitance were measured on the forearm (flexor site, $10 \mathrm{~cm}$ above wrist) with respective probes (TM300 and Corneometer CM825) attached to a Courage \& Khazaka MPA5 system [38, 39]. For SC integrity assessment, TEWL was measured following each D-squame application for a total of $4 \mathrm{D}$-squames. For barrier recovery, barrier disruption was achieved by repeated D-squame applications for a total of $7 \mathrm{D}$ squames. TEWL was measured immediately and $3 \mathrm{~h}$ after the last D-squame application. All subjects rested for at least $30 \mathrm{~min}$ at $22-24^{\circ} \mathrm{C}$, at a relative humidity of $45-47 \%$, prior to measurement. This work was performed between June and August (summer time) at Dalian Skin Disease Hospital, which is at a latitude from $38^{\circ} 43^{\prime}$ to $40^{\circ} 10^{\prime}$ north. The study protocol was approved by the Human Research Committee of Dalian Skin Disease Hospital, PR China.

\section{Statistics}

Graphpad Prism 4 software was used for all statistical analyses. A one-way ANOVA, with Tukey's correction, was used to determine significant differences, when 3 or more groups were compared, while an unpaired t test with Welch's correction was used for comparisons between 2 groups. Data are expressed as means \pm SEM.

\section{Results}

\section{Alteration of Barrier Function Induced by Sun}

Exposure Is Associated with Gender and Sun

Exposure Doses

We first assessed epidermal permeability barrier function following various doses of sun exposure in both males and females (table 1). In males, baseline TEWL was significantly higher in the group exposed to higher doses of sunlight in comparison with lower-dose and control subjects (fig. 1). In contrast, baseline TEWL in females was significantly higher in the group exposed to lower doses of sunlight as compared with higher-dose and control subjects (fig. 1). In addition, in females, TEWL in the group exposed to higher doses of sunlight was not differ- 


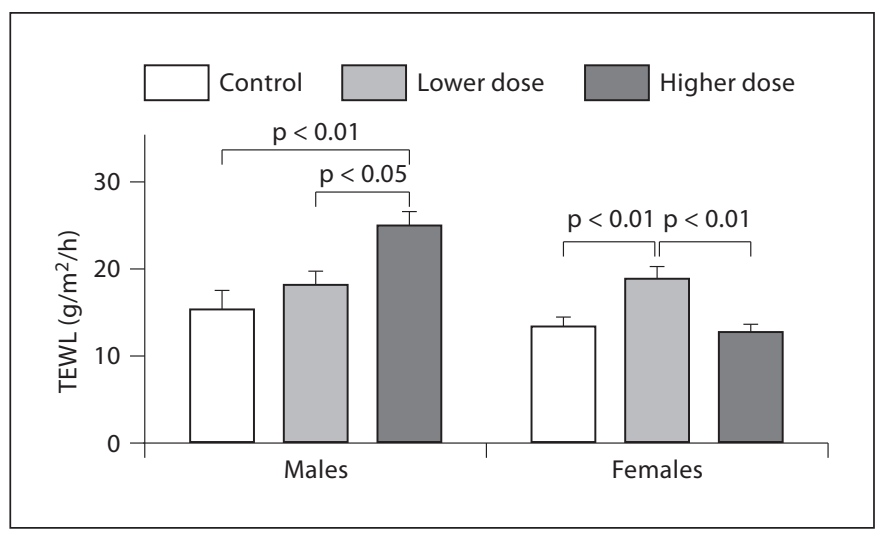

Fig. 1. TEWL baseline following various doses of sun exposure. Basal TEWLs were compared by one-way ANOVA, with Tukey's correction, which was used to determine significant differences. Significant differences are shown in the figure. The number of subjects in each group is detailed in table 1.

ent from that in controls. There was no gender difference in baseline TEWL in both control and lower-dose groups. However, baseline TEWL in males was significantly higher than that in females in the group exposed to higher doses of sunlight $(24.82 \pm 1.68$ and $12.62 \pm 1.06$ $\mathrm{g} / \mathrm{m}^{2} / \mathrm{h}$ for males and females, respectively).

Since previous studies showed that UVB radiation alters barrier recovery in animal models [29, 37], we next evaluated barrier homeostasis with various doses of sun exposure. In both females and males, barrier recovery was significantly delayed in the groups with higher doses of sun exposure as compared with lower-dose and control groups (fig. 2). There was no difference in barrier recovery between control and lower-dose groups in both males and females (fig. 2). In both control and lower-dose groups, barrier recovery was significantly slower in males than in females (in controls, males $13.08 \pm 13.21 \mathrm{vs.} \mathrm{fe-}$ males $51.23 \pm 4.25 \%, \mathrm{p}<0.01$; in the lower-dose group, males $-16.53 \pm 11.34$ vs. females $53.03 \pm 6.38 \%$, p < $0.0001)$. However, in the group exposed to higher doses of sunlight, there was no significant difference in barrier recovery between females and males.

\section{SC Integrity Varies with Gender and Dose of Sun Exposure}

As seen in figure $3 \mathrm{a}$, in males, TEWL generally increased less in sun-exposed groups than in controls following the same number of D-squame application, especially in the higher-dose group. In females, TEWL increased significantly in the lower-dose group in com-

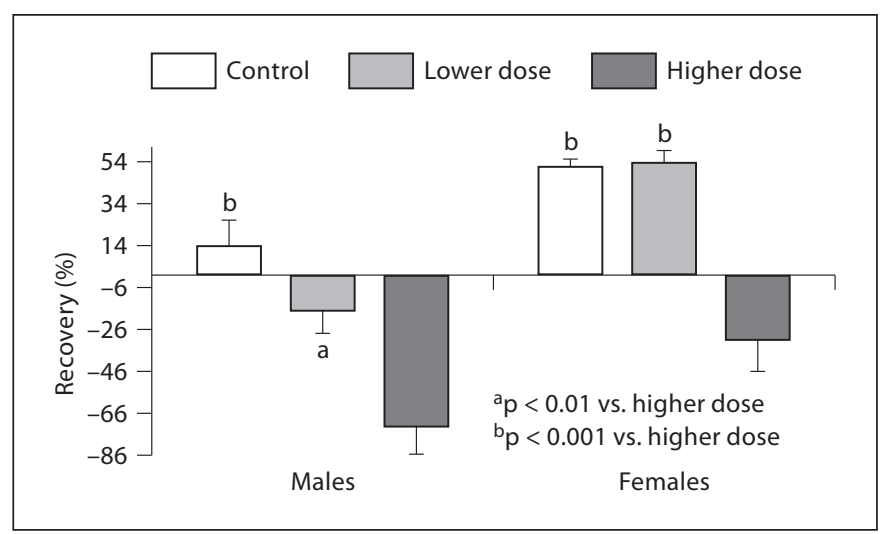

Fig. 2. Comparison of barrier recovery rates after different doses of sun exposure. The comparison of barrier recovery rates was analyzed by one-way ANOVA, with Tukey's correction. The number of subjects in each group is detailed in table 1, and significances are indicated in the figure.

Table 1. Characteristics of subjects

\begin{tabular}{|c|c|c|c|c|}
\hline & \multicolumn{2}{|c|}{ Males } & \multicolumn{2}{|c|}{ Females } \\
\hline & $\mathrm{n}$ & $\begin{array}{l}\text { mean age } \pm \text { SEM } \\
\text { years }\end{array}$ & $\mathrm{n}$ & $\begin{array}{l}\text { mean age } \pm \text { SEM } \\
\text { years }\end{array}$ \\
\hline Normal control & 28 & $28.21 \pm 1.27$ & 45 & $32.04 \pm 0.95$ \\
\hline Lower dose & 45 & $21.69 \pm 0.40$ & 50 & $30.74 \pm 0.81$ \\
\hline Higher dose & 51 & $32.96 \pm 1.00$ & 39 & $19.82 \pm 0.51$ \\
\hline Total subjects & 124 & & 134 & \\
\hline
\end{tabular}

parison with controls following 3 or $4 \mathrm{D}$-squame applications (fig. 3b). TEWL in both control and lower-dose groups also increased more in females than in males after the same number of $\mathrm{D}$-squame application, whereas the percent increase in TEWL in females did not differ significantly from that in males in the higher-dose group (data not shown). These results demonstrated that changes in SC resistance to tape-stripping induced by sun exposure are also associated with gender and amount of sun exposure.

\section{SC Hydration Varies with Gender and the Doses of Sun Exposure}

We next measured SC hydration with various doses of sun exposure. In males, there was no difference in SC hydration among control, lower and higher doses of sun exposure (fig. 4). However, in females, SC hydration was 

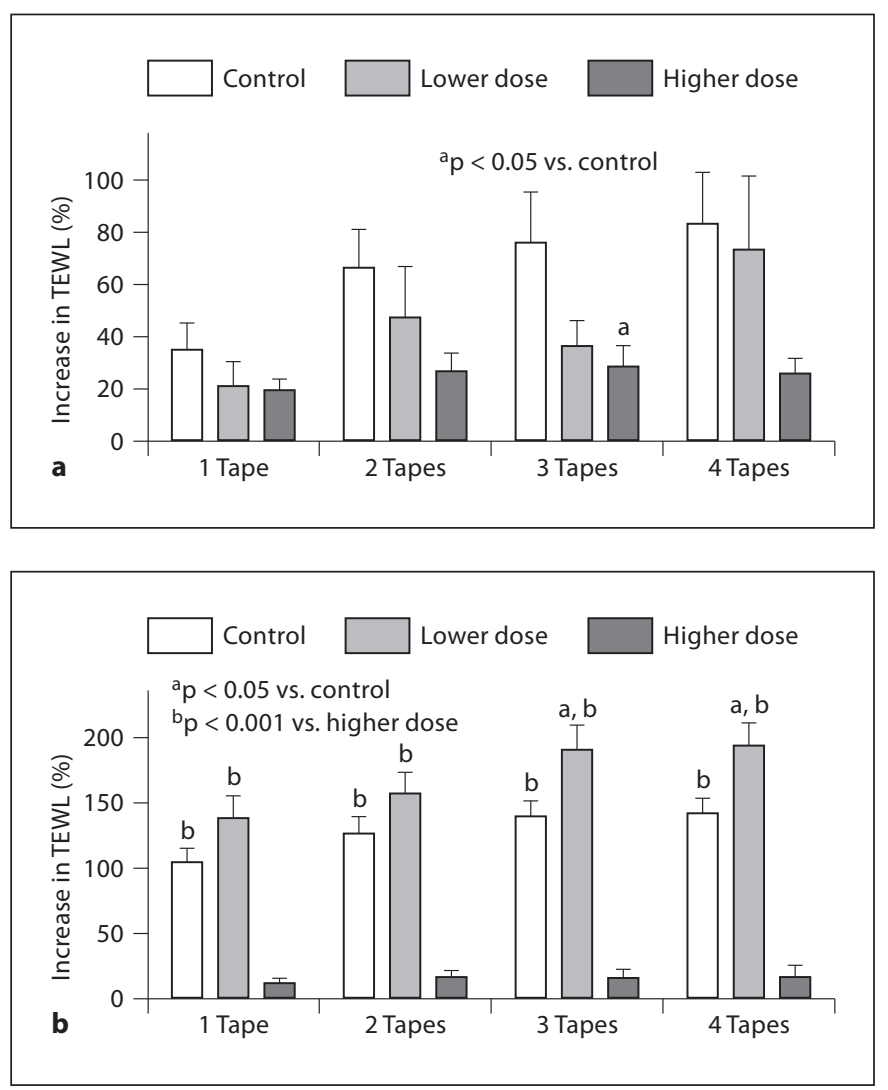

Fig. 3. Changes in SC integrity with gender and the doses of sun exposure: percent increase in TEWL following D-squame applications in males (a) and females (b). The number of subjects in each group is detailed in table 1. One-way ANOVA with Tukey's correction was used to determine the significant difference, and the significances are indicated in the figure.

significantly lower in the group exposed to lower doses of sunlight as compared with the control and higher-dose groups (fig. 4). SC hydration in females was significantly lower than that in males in both control and sun-exposed groups ( $\mathrm{p}<0.05$ for control and $\mathrm{p}<0.0001$ for both lower- and higher-dose groups). These data indicated that the influence of sun exposure on SC hydration varies with gender and doses of sun exposure.

\section{Discussion}

Alteration in cutaneous function induced by UV radiation is determined at least in part by radiating doses $[27,36]$. In contrast to the previous finding that basal TEWL in photo-aged skin is similar to that in non-photo-

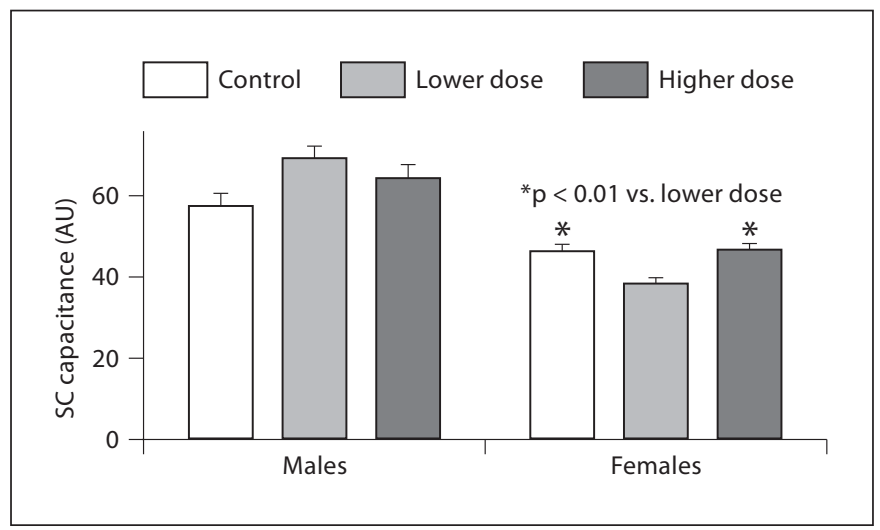

Fig. 4. Changes in SC hydration with gender. Comparison of SC hydration in the groups exposed to various doses of sunlight was made in males and females. One-way ANOVA with Tukey's correction was used to determine the significant differences. The number of subjects in each group is detailed in table 1 . The significance is indicated in the figure. $\mathrm{AU}=$ Arbitrary unit.

aged subjects aged 80-97 years [29], the present studies demonstrate that daily sun exposure does induce dosedependent changes in basal TEWL, which is in agreement with previous findings [40]. The different results may be due to the subjects' ages. The subjects' ages in the present study range from 15 to 50 years. It has been shown that UVB radiation causes more intensive erythema in older subjects [41] and induces a more dramatic increase in TEWL in younger mice ( 27 weeks old) than in older ones, which shows a minimum increase (90 weeks old) [42]. Although suberythemal UVB radiation accelerates barrier recovery in the animal model [37], in the present study no dramatic difference in barrier recovery was observed between control and lower doses of sun exposure. However, studies here show a significant delay in barrier recovery following higher doses of sun exposure. Previous studies showed that UVB radiation alters SC lipid structure and induces disorganized lamellar body and SC intercellular membrane bilayers in addition to disrupting barrier function $[43,44]$. Moreover, UVB radiation increases $\mathrm{SC} \mathrm{pH}$, which, in turn, delays barrier recovery and increases epidermal desquamation $[45,46]$. Furthermore, UVB radiation also decreases SC covalently bound ceramides and reduces epidermal differentiation proteins such as loricrin, transglutaminase type I, filaggrin and keratin K2e expression [47, 48]. Both SC lipids and differentiation are crucial for epidermal permeability [for a review, see 49, 50]. Finally, it has been shown that thymocytes play an important role in regulating permeability 
barrier function including UV-induced barrier abrogation $[36,51]$. Thus, alterations in SC lipid quality, differentiation protein expression and UVB-induced immune reaction could account for the delayed barrier recovery.

Interestingly, higher doses of sun exposure improve SC integrity (resistance to tape-stripping), especially in females, while lower doses of sun exposure cause either minimal or no changes in SC integrity. The mechanisms by which sun exposure improves SC integrity are not clear. As the permeability barrier mainly exists in the SC and the SC integrity in the present study was determined by measuring TEWL following each SC removal with Dsquame, SC thickness could influence TEWL after each SC removal. Studies have demonstrated that repeated UVB radiation increases both epidermal and SC thickness [52-55]. Therefore, more SC layers were left with higher doses of sun exposure following the same number of D-squame application in comparison with a thinner SC in the control group. Then it is not surprising that the higher-dose group exhibited lower TEWL readings than controls following the same number of SC removal. Gender difference in SC integrity is also demonstrated in the present study. SC integrity in females is significantly stronger than that in males in both control and lowerdose groups pointing to the negative impact of male sex hormones on barrier functions. In agreement with previous findings $[38,56]$, the present studies also show that SC hydration in males is higher than that in females, although sun exposure does not change SC hydration significantly as compared with controls.

In summary, the present study shows that sun exposure alters epidermal permeability barrier homeostasis and SC integrity. The extent of these changes varies with gender and the doses of sun exposure. These results suggest that improving SC function should be considered in future treatments for sun-induced skin damages.

\section{Acknowledgements}

This work was supported in part by National Institutes of Health grant AR 19098 and Chinese Medical Association-Vichy Skin Research Foundation 080923ACD1472328.

\section{References}

1 Yarak S, Ogawa MM, Hirata S, de Almeida FA: Prevalence of acquired melanocytic naevi in Brazilian schoolchildren. Clin Exp Dermatol 2009, E-pub ahead of print

-2 Naldi L, Altieri A, Imberti GL, Gallus S, Bosetti C, La Vecchia C; Oncology Study Group of the Italian Group for Epidemiologic Research in Dermatology: Sun exposure, phenotypic characteristics, and cutaneous malignant melanoma: an analysis according to different clinico-pathological variants and anatomic locations (Italy). Cancer Causes Control 2005; 16:893-899.

-3 Crijns MB, Klaver C, de Boer A, Van Hees C, Vermeer BJ, Vandenbroucke J, Bergman W: Ultraviolet exposure and the development of banal and atypical naevi - a cross-sectional study on Curaçao and in the Netherlands. Melanoma Res 1997;7:407-416.

-4 Harrison SL, MacLennan R, Buettner PG: Sun exposure and the incidence of melanocytic nevi in young Australian children. Cancer Epidemiol Biomarkers Prev 2008; 17 : 2318-2324.

5 Dulon M, Weichenthal M, Blettner M, Breitbart M, Hetzer M, Greinert R, BaumgardtElms C, Breitbart EW: Sun exposure and number of nevi in 5- to 6-year-old European children. J Clin Epidemiol 2002;55:10751081.
6 Kennedy C, Bajdik CD, Willemze R, De Gruijl FR, Bouwes Bavinck JN; Leiden Skin Cancer Study: The influence of painful sunburns and lifetime sun exposure on the risk of actinic keratoses, seborrheic warts, melanocytic nevi, atypical nevi, and skin cancer J Invest Dermatol 2003;120:1087-1093.

7 Ródenas JM, Delgado-Rodríguez M, Herranz MT, Tercedor J, Serrano S: Sun exposure, pigmentary traits, and risk of cutaneous malignant melanoma: a case-control study in a Mediterranean population. Cancer Causes Control 1996; 7:275-283.

-8 Breitbart M, Garbe C, Büttner P, Weiss J, Soyer HP, Stocker U, Krüger S, Breitbart EW, Weckbecker J, Panizzon R, Bahmer F, Tilgen W, Guggenmoos-Holzmann I, Orfanos CE: Ultraviolet light exposure, pigmentary traits and the development of melanocytic naevi and cutaneous melanoma: a case-control study of the German Central Malignant Melanoma Registry. Acta Derm Venereol 1997; 77:374-378.

-9 Whiteman DC, Stickley M, Watt P, Hughes MC, Davis MB, Green AC: Anatomic site, sun exposure, and risk of cutaneous melanoma. J Clin Oncol 2006;24:3172-3177.
10 Chang YM, Barrett JH, Bishop DT, Armstrong BK, Bataille V, Bergman W, Berwick M, Bracci PM, Elwood JM, Ernstoff MS, Gallagher RP, Green AC, Gruis NA, Holly EA, Ingvar C, Kanetsky PA, Karagas MR, Lee TK, Le Marchand L, Mackie RM, Olsson H, Østerlind A, Rebbeck TR, Sasieni P, Siskind V, Swerdlow AJ, Titus-Ernstoff L, Zens MS, Newton-Bishop JA: Sun exposure and melanoma risk at different latitudes: a pooled analysis of 5,700 cases and 7,216 controls. Int J Epidemiol 2009;38:814-830.

-11 Buckman SY, Gresham A, Hale P, Hruza G, Anast J, Masferrer J, Pentland AP: COX-2 expression is induced by UVB exposure in human skin: implications for the development of skin cancer. Carcinogenesis 1998;19:723729.

12 Trakatelli M, Ulrich C, del Marmol V, Euvrard S, Stockfleth E, Abeni D: Epidemiology of nonmelanoma skin cancer (NMSC) in Europe: accurate and comparable data are needed for effective public health monitoring and interventions. Br J Dermatol 2007; 156(suppl 3):1-7.

13 Lazaridou E, Apalla Z, Sotiraki S, Ziakas NG, Fotiadou C, Ioannides D: Clinical and laboratory study of rosacea in northern Greece. J Eur Acad Dermatol Venereol 2009, E-pub ahead of print. 
14 Klein RS, Sayre RM, Dowdy JC, Werth VP: The risk of ultraviolet radiation exposure from indoor lamps in lupus erythematosus. Autoimmun Rev 2009;8:320-324.

15 Correia I, Silva J, Filipe P, Gomes M: Solar urticaria treated successfully with intravenous high-dose immunoglobulin: a case report. Photodermatol Photoimmunol Photomed 2008;24:330-331.

16 Kikuchi-Numagami K, Suetake T, Yanai M, Takahashi M, Tanaka M, Tagami H: Functional and morphological studies of photodamaged skin on the hands of middle-aged Japanese golfers. Eur J Dermatol 2000;10: 277-281.

- 17 Hachiya A, Sriwiriyanont P, Fujimura T, Ohuchi A, Kitahara T, Takema Y, Kitzmiller WJ, Visscher MO, Tsuboi R, Boissy RE: Mechanistic effects of long-term ultraviolet $B$ irradiation induce epidermal and dermal changes in human skin xenografts. Am J Pathol 2009;174:401-413.

- 18 Lee JY, Kim YK, Seo JY, Choi CW, Hwang JS, Lee BG, Chang IS, Chung JH: Loss of elastic fibers causes skin wrinkles in sun-damaged human skin. J Dermatol Sci 2008;50:99-107.

-19 Hillebrand GG, Miyamoto K, Schnell B, Ichihashi M, Shinkura R, Akiba S: Quantitative evaluation of skin condition in an epidemiological survey of females living in northern versus southern Japan. J Dermatol Sci 2001;27(suppl 1):S42-S52.

20 Akiba S, Shinkura R, Miyamoto K, Hillebrand G, Yamaguchi N, Ichihashi M: Influence of chronic UV exposure and lifestyle on facial skin photo-aging - results from a pilot study. J Epidemiol 1999;9(6 suppl):S136S142.

-21 Sleijffers A, Garssen J, Vos JG, Loveren H: Ultraviolet light and resistance to infectious diseases. J Immunotoxicol 2004;1:3-14.

-22 Jeevan A, Sharma AK, McMurray DN: Ultraviolet radiation reduces resistance to $\mathrm{Myco}$ bacterium tuberculosis infection in BCGvaccinated guinea pigs. Tuberculosis (Edinb) 2009;89:431-438.

23 Giannini MS: Suppression of pathogenesis in cutaneous leishmaniasis by UV irradiation. Infect Immun 1986;51:838-843.

-24 Khaskhely NM, Maruno M, Uezato H, Takamiyagi A, Ramzi ST, Al-Kasem KM, Kariya K, Toda T, Hashiguchi Y, Gomez Landires EA, Nonaka S: Low-dose UVB contributes to host resistance against Leishmania amazonensis infection in mice through induction of gamma interferon and tumor necrosis factor alpha cytokines. Clin Diagn Lab Immunol 2002;9:677-686.

-25 Denkins Y, Fidler IJ, Kripke ML: Exposure of mice to UV-B radiation suppresses delayed hypersensitivity to Candida albicans. Photochem Photobiol 1989;49:615-619.
6 Kim TH, Ullrich SE, Ananthaswamy HN, Zimmerman S, Kripke ML: Suppression of delayed and contact hypersensitivity responses in mice has different UV dose responses. Photochem Photobiol 1998;68:738744.

27 Lim SH, Kim SM, Lee YW, Ahn KJ, Choe YB: Change of biophysical properties of the skin caused by ultraviolet radiation-induced photodamage in Koreans. Skin Res Technol 2008;14:93-102.

28 Wendling PA, Dell'Acqua G: Skin biophysical properties of a population living in Valais, Switzerland. Skin Res Technol 2003;9: 331-338.

29 Reed JT, Elias PM, Ghadially R: Integrity and permeability barrier function of photoaged human epidermis. Arch Dermatol 1997;133: 395-396.

30 Frödin T, Molin L, Skogh M: Effects of single doses of UVA, UVB, and UVC on skin blood flow, water content, and barrier function measured by laser-Doppler flowmetry, optothermal infrared spectrometry, and evaporimetry. Photodermatology 1988;5:187-195.

31 Li MJ, Lin SY, Liang RC: Continuous UVB irradiation to modify the biophysical properties and protein conformation of rat skin. Methods Find Exp Clin Pharmacol 2001;23: 135-139.

32 Li MJ, Lin SY, Liang RC: Changes in the skin moisture contents, skin color, and skin protein conformational structures of SpragueDawley rats after ultraviolet B irradiation. Skin Pharmacol Appl Skin Physiol 1999;12: 336-343.

33 Yamamoto T, Kurasawa M, Hattori T, Maeda T, Nakano H, Sasaki H: Relationship between expression of tight junction-related molecules and perturbed epidermal barrier function in UVB-irradiated hairless mice. Arch Dermatol Res 2008;300:61-68.

34 Jiang SJ, Chu AW, Lu ZF, Pan MH, Che DF, Zhou XJ: Ultraviolet B-induced alterations of the skin barrier and epidermal calcium gradient. Exp Dermatol 2007;16:985-992.

35 Thiele JJ, Dreher F, Maibach HI, Packer L: Impact of ultraviolet radiation and ozone on the transepidermal water loss as a function of skin temperature in hairless mice. Skin Pharmacol Appl Skin Physiol 2003;16:283290.

36 Haratake A, Uchida Y, Schmuth M, Tanno O, Yasuda R, Epstein JH, Elias PM, Holleran WM: UVB-induced alterations in permeability barrier function: roles for epidermal hyperproliferation and thymocyte-mediated response. J Invest Dermatol 1997;108: 769-775

37 Hong SP, Kim MJ, Jung MY, Jeon H, Goo J, Ahn SK, Lee SH, Elias PM, Choi EH: Biopositive effects of low-dose UVB on epidermis coordinate upregulation of antimicrobial peptides and permeability barrier reinforcement. J Invest Dermatol 2008;128:2880 2887.
38 Man MQ, Xin SJ, Song SP, Cho SY, Zhang XJ, Tu CX, Feingold KR, Elias PM: Variation of skin surface $\mathrm{pH}$, sebum content and stratum corneum hydration with age and gender in a large Chinese population. Skin Pharmacol Physiol 2009;22:190-199.

-39 Song SP, Lv CZ, Feingold KR, Hou QN, Li ZY, Guo CY, Elias PM, Man MQ: Abnormalities in stratum corneum function in patients recovered from leprosy. Skin Pharmacol Physiol 2009;22:131-136.

40 Van den Akker JT, Holroyd JA, Vernon DI, Sterenborg HJ, Brown SB: Chronic UVB exposure enhances in vitro percutaneous penetration of 5-aminulevulinic acid in hairless mouse skin. Lasers Surg Med 2004;34:141145.

41 Gloor M, Scherotzke A: Age dependence of ultraviolet light-induced erythema following narrow-band UVB exposure. Photodermatol Photoimmunol Photomed 2002;18: 121-126.

42 Haratake A, Uchida Y, Mimura K, Elias PM, Holleran WM: Intrinsically aged epidermis displays diminished UVB-induced alterations in barrier function associated with decreased proliferation. J Invest Dermatol 1997;108:319-323.

$\checkmark 43$ Merle C, Baillet-Guffroy A: Physical and chemical perturbations of the supramolecular organization of the stratum corneum lipids: in vitro to ex vivo study. Biochim Biophys Acta 2009;1788:1092-1098.

44 Jiang SJ, Chen JY, Lu ZF, Yao J, Che DF, Zhou $\mathrm{XJ}$ : Biophysical and morphological changes in the stratum corneum lipids induced by UVB irradiation. J Dermatol Sci 2006;44:2936.

45 Man WY, Liu ZL, Elias PM, Feingold KR, Man MQ: Study on the skin surface $\mathrm{pH}$ homeostasis (in Chinese). Clin J Dermatol 2009;38:152-153.

46 Houben E, Hachem JP, De Paepe K, Rogiers $\mathrm{V}$ : Epidermal ceramidase activity regulates epidermal desquamation via stratum corneum acidification. Skin Pharmacol Physiol 2008;21:111-118

47 Takagi Y, Nakagawa H, Kondo H, Takema Y, Imokawa G: Decreased levels of covalently bound ceramide are associated with ultraviolet B-induced perturbation of the skin barrier. J Invest Dermatol 2004;123:11021109.

48 Del Bino S, Vioux C, Rossio-Pasquier P, Jomard A, Demarchez M, Asselineau D, Bernerd F: Ultraviolet B induces hyperproliferation and modification of epidermal differentiation in normal human skin grafted onto nude mice. Br J Dermatol 2004;150: 658-667.

49 Kessner D, Ruettinger A, Kiselev MA, Wartewig S, Neubert RH: Properties of ceramides and their impact on the stratum corneum structure. 2. Stratum corneum lipid model systems. Skin Pharmacol Physiol 2008;21:58-74. 
-50 Scharschmidt TC, Man MQ, Hatano Y, Crumrine D, Gunathilake R, Sundberg JP, Silva KA, Mauro TM, Hupe M, Cho S, Wu Y, Celli A, Schmuth M, Feingold KR, Elias PM: Filaggrin deficiency confers a paracellular barrier abnormality that reduces inflammatory thresholds to irritants and haptens. J Allergy Clin Immunol 2009;124: 496-506.

-51 Barai ND, Supp AP, Kasting GB, Visscher MO, Boyce ST: Improvement of epidermal barrier properties in cultured skin substitutes after grafting onto athymic mice. Skin Pharmacol Physiol 2007;20:21-28.
Lavker RM, Gerberick GF, Veres D, Irwin CJ, Kaidbey KH: Cumulative effects from repeated exposures to suberythemal doses of UVB and UVA in human skin. J Am Acad Dermatol 1995;32:53-62.

53 Sano T, Kume T, Fujimura T, Kawada H, Higuchi K, Iwamura M, Hotta M, Kitahara T, Takema Y: Long-term alteration in the expression of keratins 6 and 16 in the epidermis of mice after chronic UVB exposure. Arch Dermatol Res 2009;301:227-237.

54 Moloney SJ, Edmonds SH, Giddens LD, Learn DB: The hairless mouse model of photoaging: evaluation of the relationship between dermal elastin, collagen, skin thickness and wrinkles. Photochem Photobiol 1992;56:505-511.
55 Kambayashi H, Yamashita M, Odake Y, Takada K, Funasaka Y, Ichihashi M: Epidermal changes caused by chronic low-dose UV irradiation induce wrinkle formation in hairless mouse. J Dermatol Sci 2001;27(suppl 1):S19-S25.

56 Xin SJ, Liu ZL, Shi YJ, Feingold KR, Elias PM, Man MQ: Study on the sebum content and stratum corneum hydration in the normal Chinese population (in Chinese). J Clin Dermatol 2007;36:131-133. 